\title{
Organisation of asthma care: what difference does it make? A systematic review of the literature
}

\author{
Alison J Eastwood, Trevor A Sheldon
}

\begin{abstract}
Objectives-To evaluate the effectiveness of different forms of organisation (delivery) of asthma care.

Methods-A systematic review of the published evidence of effectiveness organisational methods of asthma management. Searches on computerised databases including Medline, CINAHL, and HELMIS, and relevant citations and letters to experts were used to identify relevant studies.

Results-27 studies were identified that evaluated different organisational methods of delivery across both primary and secondary sectors, such as shared care, general practice asthma clinics, outpatient programmes, inpatient admissions policies, and the use of specialists. Only one third of the studies used a randomised controlled trial and many had small sample sizes. No conclusive evidence was found to favour any particular organisational form, although limited evidence would suggest that specialist care is better than general care and that shared care can be as effective as hospital led care.

Conclusions-There is little good published research evaluating different ways of organising the delivery of asthma care. There is need for good quality research on organisational methods of delivery of asthma care that could be used to inform policy makers, in particular examining whether patients treated by healthcare professionals with expertise and interest in asthma will experience better outcomes.

(Quality in Health Care 1996;5:134-143)
\end{abstract}

Keywords: asthma care, randomised controlled trial, systematic review, organisation of care

\section{Introduction}

Asthma is a common chronic condition that affects both children and adults, that calls on the skills of various healthcare professionals and services in both the primary and secondary care sectors. The quality of asthma care varies and there is evidence of poor treatment in both hospitals ${ }^{1}$ and general practice. ${ }^{2}$ The education of junior doctors in the United Kingdom is still lacking, ${ }^{3}$ and general practitioners, pharmacists, paediatric nurses, and nurses in community asthma clinics have deficiencies in knowledge. ${ }^{45}$ For example, inadequate training in metered dose inhaler techniques was found in a significant proportion of healthcare providers dealing with asthmatic patients. ${ }^{6}$
Consensus based national clinical practice guidelines for the management of asthma have been developed by professional organisations, ${ }^{7-9}$ and revised guidelines are soon to be published. Although the guidelines were supported by reviews of the published literature no distinction is made between evidence and consensus based statements, and they have not been subject to rigorous evaluation. There is little evidence to suggest that the guidelines have improved standards of care. Studies have shown that asthma management diverges from that recommended in guidelines, ${ }^{10} 11$ even in a specialist respiratory unit. ${ }^{12}$ Keeley emphasises the need to ensure the comprehensive implementation of the current knowledge about asthma management in general practice. ${ }^{13}$

Little attention has been paid to how care should be delivered and by whom - the organisational aspects of the delivery of care, the modes of delivery of service as opposed to the treatments themselves. For example, how should asthma management be structured? Within primary care should treatment be given through general practitioner consultations, nurse consultations, or an asthma clinic? Should patient review be formalised or opportunistic? There are also issues of which personnel should provide treatment. Do specialists provide more effective treatment than generalists? Should trained asthma nurses or community nurses be involved in the management of asthma?

In the past few years there has been organisational change within the provision of health care. For example, in the United Kingdom the most recent "general practice contract health promotion package" includes fixed payments for chronic disease management programmes for asthma and diabetes, as an incentive to care for chronic illness in primary care. ${ }^{14}$ This had led to a large increase in the number of practice nurses, who may be involved in the care of asthmatic patients, and is part of a general shift towards primary care in the purchase and provision of care. ${ }^{15}$ The assumption is that shared care will have an impact on quality, over and above that obtained from specific treatments. ${ }^{16}$

These changes have been made on the assumption that these forms of organisationfor example, shared care, practice nurses-are beneficial. The aim of this paper is to explore the knowledge base by reporting the results of a systematic review of the research on the effectiveness of different forms of organisation of asthma care. 


\section{Methods}

To identify studies, the Medline database was searched from 1976 to the first quarter of 1995, with the search terms given in the appendix. The CINAHL, HELMIS, Manchester Primary and Secondary Care Interface, Health Planning and Administration, and DHSS databases were also searched, with the keyword "asthma". Relevant citations from identified articles were retrieved. A letter was sent to members of the national asthma guidelines working party, ${ }^{9}$ to solicit their assistance in identifying articles.

Studies were included that evaluated organisational methods of asthma management, and were written in English. No study design limitations were imposed due to the small volume of research literature in this area. Data were extracted on to structured abstract sheets.

Studies are categorised into the following broad settings: emergency; inpatient; outpatient; community; general practice; and integrated or shared care. Within settings, when appropriate, studies are grouped according to the healthcare professional involved in the intervention: general practitioner, nurse, school doctor, community nurse, school nurse, and respiratory and general physicians. Many issues will be relevant across more than one setting or professional group.

Studies are graded by the reliability of their results according to study design-the randomised controlled trial being considered the most reliable source of evidence. ${ }^{17}$

\section{Results}

Twenty seven studies were identified, only nine of which were randomised controlled trials. The other designs were non-randomised controlled trials (four studies), and observational series (14 studies), mainly before-after studies, audit, and descriptive reports. Table 1 shows detailed summaries of the individual studies.

SHARED CARE (ONE STUDY)

The GRASSIC study used a randomised incomplete block design to assess the effectiveness of shared care between outpatient specialist and general practitioner. The authors suggest that shared care is as effective as conventional outpatient care $^{18}$ and cheaper from the perspective of hospitals, general practice fundholders, and patients. The total cost for shared care was $£ 101$ / patient / year, compared with $£ 141$ for conventional care (1991/92 prices). ${ }^{19}$ A survey of a random sample of general practitioners involved in the GRASSIC study showed that general practitioners were enthusiastic about the principles of shared care for asthma and reported good communication with hospital consultants. ${ }^{20}$ Without successful communication, the effectiveness of the scheme might be compromised.

ASTHMA CLINICS IN GENERAL PRACTICE (FOUR STUDIES)

There are no randomised controlled trials evaluating asthma clinics in general practice. Of the four studies identified two evaluated clinics run by general practitioners and two by nurses. A matched controlled before-after comparison of children attending a mini-clinic run by the general practitioner and those receiving conventional asthma care through general practice consultations found no difference in morbidity measures, except for a decrease in all cause school absence. ${ }^{21}$ In another uncontrolled study the introduction of an asthma clinic resulted in patients being more easily identified, but overall clinical improvement among asthma patients was not obvious. $^{22}$

Two uncontrolled before-after studies of different groups of patients in the same nurse run asthma clinic reported significant, although not always sustained, improvement in morbidity for patients. ${ }^{2324}$ The authors also suggest that a clinic run by a nurse provides a setting where patients who feel unable to talk to their general practitioner can get more information about asthma.

One problem with asthma clinics is the time commitment required by healthcare professionals. This was highlighted as an issue in both clinics run by general practices, where the clinic was unable to cope with the number of patients, ${ }^{22}$ and also in clinics run by a nurse, where it was thought that the duration of the consultation in the trial may not be sustainable under normal circumstances. ${ }^{23}$

ASTHMA CONSULTATIONS IN GENERAL PRACTICE (THREE STUDIES)

Three studies considered aspects of asthma care delivered through conventional general practice consultations. A randomised controlled trial evaluated the use of an audit facilitator to influence the outcomes of children with asthmatic symptoms. The children were targeted for clinical review by either their general practitioner or practice nurse. The trial found that the facilitator favourably influenced the diagnosis and treatment of childhood asthma, but had an inconclusive impact on clinical outcome. ${ }^{25}$ It also reported a shift in costs from hospital to primary care.

Uncontrolled before-after studies of two audits ${ }^{26}$ and the implementation of a consensus management plan ${ }^{27}$ reported conflicting results on the likely impact of initiatives to improve the quality of care in general practice and are unreliable.

COMMUNITY BASED PROVISION (SIX STUDIES)

The six studies identified, all aimed at children with asthma, evaluated different interventions with a variety of healthcare professionals: community nurses, general practitioners, school nurses, school doctors, and community health workers. $^{28-33}$

Three studies evaluated interventions involving community nurses, two of which were randomised controlled trials, ${ }^{28} 29$ and one of which was a before-after study. ${ }^{30}$ In general the randomised controlled trials reported improvements in parents' or teachers' knowledge about asthma (and consequently their ability to discriminate the severity of attacks) but no reduction in outcomes such as 
school absenteeism or exclusion from games lessons due to asthma. ${ }^{28} 29$ One of the trials was stratified by ethnic group (European and Polynesian), and suggested that interventions need to be culturally relevant. ${ }^{29}$ This was also reinforced by the before-after study which evaluated a community outreach programme and highlighted the need to deal with the specific requirements of different ethnic groups. ${ }^{30}$

The other three studies all involved different healthcare professionals. One randomised controlled trial evaluated a primary school intervention, in which school nurses were trained to educate teachers and check children's inhaler technique, and general practitioners were asked to follow guidelines. ${ }^{31}$ This led to an increase in teachers feeling able to supervise asthmatic children and children being allowed to keep inhalers with them at school, but no change in morbidity measures. A before-after study evaluated a community based asthma campaign led by school doctors which also reinforced the benefit of educating teachers. ${ }^{32}$ Butz et al provide a description of the use of community health workers to provide and obtain limited information from low income families with asthmatic children. ${ }^{33}$

OUTPATIENT PROVISION (SIX STUDIES)

Six studies were identified in total, ${ }^{34-39}$ two of which incorporated links with the community or primary care..$^{34}$ All of the interventions evaluated required the presence of a specialist nurse, and physicians were involved in three. ${ }^{34-37}$

Two randomised controlled trials considered evaluations in an outpatient setting with links to the community or primary care. Children living in the inner city, assessed in an outpatient clinic by a paediatric respirologist, and having subsequent home visits by a nurse had better outcomes than those receiving standard treatment by a primary care physician (although the study groups were not comparable at baseline). ${ }^{34}$ Another randomised controlled trial found that patients referred to an asthma clinic in a paediatric outpatient department run by a nurse who provided education, information, and reminders for primary care review, ${ }^{35}$ tended to improve their asthma control.

Four studies, all based in North America, considered interventions based solely within outpatient departments. ${ }^{36-39}$ In the only randomised controlled trial, an intensive treatment and educational programme run from a special clinic was evaluated. ${ }^{37}$ Patients received treatment from one physician and a full time nurse practitioner and were encouraged to contact staff at the clinic at any time. The intervention resulted in a reduction both in hospital admission and day use compared with a routine outpatient clinic. It was also concluded that nurse practitioners may well be as effective as physicians in educating non-compliant adult asthmatic patients. Two non-randomised controlled trials compared routine standard care with educational interventions run by nurses. These aimed at improving standards of care in poorly controlled noncompliant children ${ }^{38}$ and self management skills in asthmatic children and their parents. ${ }^{39}$ Both studies reported an improvement in outcomes and a savings in costs in the intervention compared with the control group, although both studies were small and the impact of potential confounders was not considered.

INPATIENT PROVISION (FOUR STUDIES)

Three of the four studies ${ }^{40-43}$ with inpatient settings compared the treatment given by specialist and generalist physicians. A prospective study of patients allocated to specialist or generalist care on the basis of day of admission (pseudorandomisation), found that those patients admitted to general medical units with a specialist respiratory physician were significantly more likely to be prescribed oral steroids, have objective measurements of lung function, and have their inhaler technique assessed than those admitted to units without a specialist. ${ }^{40}$ The short term follow up reported significantly fewer symptoms and readmissions for asthmatic patients allocated to specialist care. The apparent advantage of respiratory physicians compared with non-respiratory physicians was also reported in two audits providing evidence of limited strength. ${ }^{41} 42$

The use of a hospital self admission scheme for severely asthmatic patients is reported by Crompton et al. ${ }^{43}$ This is a retrospective description of a scheme which has been in use for 15 years. The scheme is reported to give confidence to both patients and general practitioners.

EMERGENCY PROVISION (THREE STUDIES)

Three studies were identified which evaluated interventions in an emergency department. ${ }^{44-46}$ A randomised controlled trial of an education programme based in an emergency department evaluated the impact of having a healthcare professional who also has asthma to provide information, based on the hypothesis that interpersonal similarity will improve communication as well as the provision of education. ${ }^{44}$ The study suggests that the role of information was modified by the means of delivery, with a significant improvement when educational information was provided by an asthmatic nurse compared with a nonasthmatic nurse. Unfortunately the follow up reported for this study was only short term (two weeks), although the trial had a final observation period of six months.

Neither of the other two trials identified were randomised controlled trials and so the results must be interpreted with caution. A non-randomised single blind observational design was used to evaluate a short verbal presentation to residents on emergency department rotation in terms of acute and discharge treatments. ${ }^{45}$ This study found that the intervention was associated with an improvement in prescribing, but was only partially effective in optimising discharge treatment. The replacement of senior house officers (SHOs) with registrars for decisions on admissions, and the education of SHOs were evaluated in a before-after study. ${ }^{46}$ Both interventions were associated with improve- 
ments in the admission policy after compared with before implementation.

\section{Discussion}

There has been little research on differing methods of organising or delivering asthma care.

The GRASSIC study provided evidence that shared care may be marginally more cost effective than conventional outpatient care. However, more research is required to identify which types of patients are suitable for shared care,$^{20}$ and to examine whether this effect is confined to enthusiastic general practitioners or could be generalised. Asthma clinics may facilitate communication between professionals and patients, and those run by asthma nurses may provide more time for patients to increase their knowledge and confidence. However, there is little evidence to suggest that such clinics can lead to a long term sustained improvement in patient morbidity. Community based programmes may prompt more appropriate use of health care by hard to reach asthmatic patients, if tailored to the needs of the target group (for example, making programmes culturally relevant to specific ethnic groups). ${ }^{47}$ Most interventions which aimed to provide more education and information to patients or parents did seem to succeed in improving knowledge and confidence, but not necessarily morbidity.

Research is needed to look at dissemination and implementation of specific programmes as well as their content. ${ }^{48}$ For example, effective communication between different groups of professionals and also between professionals and patients may be central to the effective implementation of care. ${ }^{3549-51}$

The issue of who delivers asthma care seems to influence outcomes and may be independent of where care is delivered. It is possible that, in any setting, patients may benefit more when treated by healthcare professionals with expertise and interest in asthma. However, research on this question has been limited, despite its importance for the organisation of care across all settings. Greenhalgh, in her review of shared care for diabetes, concluded that: "structured care by general practitioners with an interest in diabetes and supported by an enthusiastic and committed specialist liaison team produces comparable levels of care to that provided in hospital, but that unstructured care by disinterested and unsupported general practitioners is ineffective and wasteful of resources." 52

Insufficient education of healthcare professionals in the treatment of asthma may explain in part why specialist care may yield better outcomes for inpatient care than that provided by general physicians. However, a comparison of two groups of specialists (consultant physicians with an interest in chest diseases and paediatricians who manage children with asthma) found variation between and within groups in their opinions on the appropriate management of asthma. ${ }^{53}$ Further good quality research is required to assess the impact of levels of exper-
Top 10 research and development priorities for the NHS on asthma management $^{55}$

- Delineation of predictors of response to the treatment of wheezing illness in children - Evaluation of interventions based on individual patients or households to prevent the development of asthma, reduce it severity or improve its prognosis

- Synthesising and evaluating outcome measures for asthma in adults and children - Review of gaps in evidence for current guidlines on asthma management, followed by primary research to address these

- Evaluation of risks, benefits, and costs of long-term use of treatment for asthma

- Social and psychological influences on use of asthma services leading to the development and evaluation of strategies to address these

- Identification and management of patients at risk from severe attacks of asthma

- Evaluation of methods of communication between health professionals (including asthma nurses) and patients, teachers, and carers

- Evaluation of models of delivery of care for asthma management in different settings - Investigation of beliefs and behaviour of patients with asthma

tise and interest on the quality of asthma care.

The evidence available is not only limited by the quantity but also the quality of the research. Few studies used randomised controlled trials; in general the studies were simple before-after uncontrolled studies (both retrospective and, less often, prospective), or non-randomised comparative studies. These do not usually adjust for confounding factors in their analyses, which can lead to biased estimates. For example, several studies had non-comparable groups, differing by factors likely to influence outcome such as differing age and sex. It is thus impossible to attribute differences in outcome to the intervention. Poorly controlled studies are likely to give biased estimates because of the often large spontaneous changes in health status.

Many of the studies have too small a sample size. Further, it is difficult to judge whether statistically significant differences are actually clinically significant. In general, patients studied may not be representative and are likely to be more compliant and enthusiastic, and so the reported effect of any intervention may be more pronounced.

It is particularly difficult to evaluate organisational issues; location, structure, personnel, treatment, etc, all play a part but it is difficult to disentangle the impact of each one. Trials are usually designed to evaluate a specific intervention in terms of the treatment given. The organisational component is often ad hoc or lacking.

The results of this review largely confirm a 
United States report which stated that: "there has been virtually no systematic research examining the relationship between organizational forms in the health care system and asthma outcomes". ${ }^{4}$

An expert advisory group was recently set up to identify priorities for the National Health Service research and development programme on asthma management. ${ }^{55}$ The evaluation of models of delivery of care for asthma management in different settings, is one of the top 10 priorities identified (box).

Insufficient attention has been given to packages of care, settings of care, and healthcare professional's skills, which this review suggests might be important. Further, there is little evidence to support the organisational changes which are currently taking place, reflecting the trend from secondary to primary care. Randomised controlled trials of sufficient size with economic analysis are required to provide this evidence. It is vital to identify the specific aspects of organisation and delivery of care. For example, to evaluate the impact of professional interest, trials could be stratified according to whether the professional had an interest in asthma. It is necessary to be certain exactly which aspects of organisation the research is considering, and to undertake research which isolates these individual effects and the interactions between them.

In most studies resource implications are not considered. It is important to assess both the patient related and healthcare related costs of any intervention, not only in terms of costs to the health services involved, but also any shifting of costs to other sectors which may occur as a result of the intervention.

Table 1 Studies reporting on organisational aspects of the delivery of asthma care

\begin{tabular}{|c|c|c|c|}
\hline Study & $\begin{array}{l}\text { Study population, } \\
\text { setting, study } \\
\text { design, and size }\end{array}$ & Intervention & $\begin{array}{l}\text { Outcomes } \\
\text { measured, } \\
\text { follow up }\end{array}$ \\
\hline $\begin{array}{l}\text { Integrated care: } \\
\text { Drummond et al } \\
(1994)^{18}\end{array}$ & $\begin{array}{l}\text { Asthmatic } \\
\text { patients attending } \\
\text { UK outpatient } \\
\text { clinic. Pragmatic } \\
\text { randomised } \\
\text { incomplete block } \\
\text { design, } \mathrm{I}=363 \\
\text { patients, } \mathrm{C}=438 \\
\text { patients. }\end{array}$ & $\begin{array}{l}\text { Evaluation of integrated } \\
\text { asthma care: I: } \\
\text { Questionnaire sent to } \\
\text { patient (prompting GP } \\
\text { consultation) and GP. } \\
\text { Documentation } \\
\text { returned to specialist, } \\
\text { patient's records are } \\
\text { updated. Copy returned } \\
\text { to the GP along with any } \\
\text { recommendation for } \\
\text { changes in management. } \\
\text { C: Regular outpatient } \\
\text { care. Questionnaire sent } \\
\text { before each visit. }\end{array}$ & $\begin{array}{l}\text { Use of } \\
\text { medication; GP } \\
\text { consultations and } \\
\text { hospital } \\
\text { admissions; } \\
\text { restrictions on } \\
\text { normal activity; } \\
\text { psychological } \\
\text { aspects; patient } \\
\text { satisfaction; and } \\
\text { costs. } 12 \text { month } \\
\text { follow up. }\end{array}$ \\
\hline
\end{tabular}

Results

Comments

No significant differences between groups A well designed study. No for most outcomes. I: significantly more details are reported of likely to be in control of their asthma "all those patients who the time" and less likely to be "very declined to take part or satisfied" with the medical care they received. C: were more likely to perceive conventional care as their both advantages and disadvantages of asthma was deemed too integrated care. Integrated care estimated severe. to save the hospital $£ 3.06$, the GP (fundholder) $£ 2.41$, and the patient $£ 39.52$ per patient per year (1991 prices). The evidence suggests that integrated care is a cost effective management option in comparison with conventional outpatient care, for patients, GPs, and hospital consultants.

General practice -

Usherwood et al $(1988)^{21}$
Asthmatic

children in two group practices in Scotland.

Non-randomised controlled study. $\mathrm{I}=\mathrm{C}=31$ patients (24 males).

Martys $(1992)^{22} \quad$ Asthmatic patients in a Derbyshire

practice. Pre and postclinic audit.

161 patients preclinic 238 patients

postclinic.

Charlton et al $(1992)^{23}$

Charlton et al $(1991)^{24}$ or sodium cromoglycate in

Norfolk.

Before-after study. 105 patients.

GP patients using prophylactic
Asthma mini-clinic for hildren: I: GP chest clinic after school hours. $2-12$ weekly intervals as necessary. C: Children from neighbouring practice receiving conventional GP care, matched to I by age and sex.

GP run asthma clinic: first consultation emphasises patient education, PEFR measured at each visit, diary card issued. Subsequent visits at 6 monthly intervals or more frequently if necessary.

GP patients using Nurse run asthma clinic: inhaled steroids 45 minute appointment treatment, in Norfolk.

Before-after

study. 115

patients ( 31 wen

for only 1 or 2 appointments) taking history, checkin technique, education, self management plans. 15 minute follow up appointment after one week. Check ups at least every 8 weeks.

Nurse run asthma clinic: 45 minute appointment taking history, checking technique, education, self management plans. 15 minute follow up appointment after one week. Check ups at least every 8 weeks.
Medication, school absence, consultations, parental reported symptoms. 12 month follow up.

There was no notable difference between children in both groups preintervention. Postintervention there was no difference, except a decrease in school absence, fewer GP consultations, home visits, and out of hours visits for group I. Frequent follow up brought little benefit and has been discontinued.

Asthma in computer problem list, PEFR, smoking, review in previous year asthma medication. 1 year postclinic audi

Attitude and morbidity questionnaire. 12 months follow

Preclinic asthma prevalence of $4 \%$ postclinic of $6 \%$. Significantly more patients had the term asthma in their problem list, PEFR measurements, and their smoking history recorded.

Asthmatic patients are more easily identified, overall clinical improvement among patients is more difficult to detect.

Significant reduction in morbidity and fall in number of days lost from work or school, but not in number of patients taking time off. Significant reduction in stigma score and confidence in self care, but no difference in confidence in doctor. Weak association between morbidity and stigma.

Patient morbidity (drugs, nebulisations, Significant decrease in GP asthma consultations after introduction of clinic, but not sustained in 2nd 6 months. Significant decrease in total number of consultations). 12 oral steroid courses. For all morbidity months follow criteria, there was a drop in the first 6 up, pre and postinitial visit. months with rebound in the next. Practice and patient care organisation Practice and patie
was improved.
No comparison of absolute consulting patterns between the two practices. School absence could be due to non-asthma causes, or GP visits for group C (I group clinic was after school hours).

Only $38 \%$ of postclinic patients had a review in the past year. The clinic should ensure two visits per year. It was not able to cope with the volume of patients. No demographic comparisons of the before and after groups are made.

Age and sex distribution of respondents differed from all asthmatic patients identified in the clinic (no statistical analysis was reported). Attenders may be a biased group.

The same clinic is studied for a different population in Charlton et al (1992) ${ }^{23}$ Patient numbers in some of the subgroup comparisons were very small. No comparison made between attenders and non-attenders. 


\begin{tabular}{llll}
\hline Study & $\begin{array}{l}\text { Study population, } \\
\text { setting, study } \\
\text { design, and size }\end{array} \quad$ Intervention & $\begin{array}{l}\text { Outcomes } \\
\text { measured, } \\
\text { follow up }\end{array}$ & Results \\
\hline
\end{tabular}

General practice -

asthma

consultations:

Children with symptoms suggestive of asthma, in a sample of 12 Scottish general practices. Randomised controlled trial (stratified by age and asthma treatment) $I=1585$ patients, $\mathrm{C}=1563$ patients.

Audit facilitator in general practice. Information/equipment for opportunistic review of asthmatic children. I: Case records marked

with asthma chart, protocol, GP letter requesting patient review, and guidelines.

Each practice received education materials, inhaler devices, portable nebulisers. C: Unmarked records, but same GPs, thus heightened asthma awareness.

Barritt et al (1991) ${ }^{26} \quad$ Asthmatic patients in a Shropshire training practice. Repeat audit 1984 and 1987. 126 (1984); 192 (1987); 85 patients (both years)

\section{Minimal asthma care} through GP consultations in surgery hours (aims: diagnosis, home peak flow meters and inhaled bronchodilators with nebulisers,

bronchodilator education and prophylactics, regular follow up).

$\begin{aligned} \text { Modell et al }(1983)^{27} & \text { Asthmatic } \\ & \text { patients in a } \\ & \text { London group } \\ & \text { practice (8 GPs, } \\ & 13000 \text { patients). } \\ & \text { Before-after case } \\ & \text { study. }\end{aligned}$

Consensus asthma management plan drawn up by GPs, emphasising drug treatment, discussion, education, self management. Plan implemented on spontaneous asthma consultation.

\section{Community:} Carswell et al $(1989)^{28}$

Mitchell et al $(1986)^{29}$

Greineder et al $(1995)^{30}$
Families of asthmatic children in Avon (1 urban, 1 suburban practice). Randomised controlled trial. $\mathrm{I}=\mathrm{C}=43$ families

Home visiting community nurse specially trained in asthma. I: discussion of asthma (risks, treatment, preventing/curtailing attacks). Judgement as to visits required. C: no details of control group given.

European and Asthma education by Polynesian community child health asthmatic children discharged from paediatric medical wards, New Zealand. RCT stratified by ethnicity I: 94 European, 84 Polynesian C: 106 European, 84 Polynesian. asthma, being treated in an urban HMO centre in Boston, USA. Before-after study, $\mathrm{n}=53$. meters), individualised Children with nurses in the home. I: 6 monthly home visits by nurse (explain asthma, provoking factors, drugs, stimuli avoidance, drug compliance, encourage

follow up and GP rathe than emergency department). C: No details given

Asthma outreach: one to Emergency visits one orientation with nurse (management, medication, triggers,

inhalers, peak flow treatment programme, regular contact. of hospital for primary care, ability to manage attacks at home. 18 months follow up (12 and hospital admissions. 6-24 months follow up. $38 \%$ enrolled $\geq 1$ year.
Asthma consultations, diagnosis, and assessment, prescriptions (respiratory drugs), hospital attendences, health service costs. 12 month follow up.

Structured questionnaire,

PEFR, inhaler

technique.

Intervention

implemented

after audit. 3 year

follow up. disability and symptoms attitudes and knowledge of asthma. 1 year (20\% drop out).

PEFR, asthma symptoms, theoretical Correlation between number of visits and change in TKS over 6 months. No questionnaires. 6 month follow up.

Drugs, school absence, hospital readmissions, use between Polynesian I and $\mathrm{C}$ groups for any of the outcome measures during either time frame. Low response for Polynesian parents.

Emergency visits Correlation between admission to

Significant increase in consultations, new and reaffirmed diagnosis of asthma in year 2 , oral bronchodilator and inhaled cromoglycate. Increased use of (t) peak flow meters, steroids, and inhaled (ate of consultation for respiratory diseases (non-asthma) and prescriptions for tibiotics, cough linctus. Diagnosis and treatment of childhood asthma in general practice were favourably influenced by
audit facilitator. Changes in general practice care lead to increased primary care costs and may decrease hospital costs.

Improvements in all objectives for good and inhal prophylactic steroids. $40 \%$ of patients with high disability scores defaulted from/or were resistant to starting prophylactic treatment. No sifferences in disability scores

Little change in patients' satisfaction and knowledge. Just under half the patients were dissatisfied with their understanding of asthma and the GPs' explanations. Severity reduction most pronounced in children. A few patients remained severely affected, most had not been appropriately assessed or adequately

Significant improvement in PEFR for I difference in absence from work or school. Direct cost of nurse estimated at 4.30 per visit. Nurses improved the ability to discriminate severity of attack of the nurse.

European children significantly

socioeconomically advantaged, taking more medications than Polynesians. more drugs, had more readmissions, and used the hospital service for primary care more often than $C$. This was not hospital and black ethnicity. Significant decrease in hospital admissions and theophylline, oral bronchodilators, care, except knowledge about

Small sample size (especially those with at $\$ 76200$ (1993 prices). Enrolled patients RCT currently ongoing. experienced a significant reduction in use Highlights need to deal of emergency ward and hospital with special requirements admissions, resulting in reduced cost of of different ethnic groups. care.

Some of the data resented implies differences in groups at the period effect use data from the $\mathrm{C}$ group only. Analysis is with absolute numbers of consultations/hospital days, rather than number f patients with consultations/ hospital days as freque

Comparisons between groups are difficult (they they independent). No statistical tests were carried out for some of the findings.

Children's response may be influenced by parents, but difficult to estimate in which direction. Difficult to judge

representativeness. Raises GP-patient communication needs.

No randomisation details or comparison of groups. Asthma severity not given $41 \%$ missing data for some measurements. No follow up to see if improvements were maintained.

Low response rate for 2 nd questionnaire in Polynesian families. No comparison between $\mathrm{C}$ and I groups undertaken. 


\begin{tabular}{|c|c|c|c|c|c|}
\hline Study & $\begin{array}{l}\text { Study population, } \\
\text { setting, study } \\
\text { design, and size }\end{array}$ & Intervention & $\begin{array}{l}\text { Outcomes } \\
\text { measured, } \\
\text { follow up }\end{array}$ & Results & Comments \\
\hline Hill et al $(1991)^{31}$ & $\begin{array}{l}\text { Nottingham } \\
\text { primary school } \\
\text { children with } \\
\text { absence in the } \\
\text { previous year, } \\
\text { taking no } \\
\text { treatment or } \beta \\
\text { agonists only. } \\
\text { Randomised } \\
\text { controlled trial. I: } \\
49 \text { schools, } 228 \\
\text { children C: } 52 \\
\text { schools, } 223 \\
\text { children. }\end{array}$ & $\begin{array}{l}\text { Simple intervention } \\
\text { programme in primary } \\
\text { schools. I: Parents asked } \\
\text { to take their child to the } \\
\text { GP. GPs asked to follow } \\
\text { guidelines and fill in a } \\
\text { questionnaire. School } \\
\text { nurses trained to } \\
\text { educate teachers and } \\
\text { check technique. C: } \\
\text { Filled in outcomes } \\
\text { questionnaire. }\end{array}$ & $\begin{array}{l}\text { School absence, } \\
\text { missed games } \\
\text { and swimming } \\
\text { lessons, school } \\
\text { policy towards } \\
\text { asthma } \\
\text { management. } 12 \\
\text { month follow up. }\end{array}$ & $\begin{array}{l}\text { No significant changes in participation in } \\
\text { school activities or morbidity measures. } \\
\text { Significant difference in children keeping } \\
\text { inhalers in school and using inhalers } \\
\text { before games between I and C groups. } \\
\text { Teachers in I schools were more likely to } \\
\text { feel prepared to supervise asthmatic } \\
\text { children. Teacher education was } \\
\text { successful in increasing teachers' } \\
\text { knowledge and confidence. The } \\
\text { intervention may be more effective in } \\
\text { areas where the prevalence of diagnosed } \\
\text { asthma is lower. }\end{array}$ & $\begin{array}{l}\text { Randomisation by school, } \\
\text { no comparison of schools } \\
\text { preintervention. Loss to } \\
\text { follow up of } 34 \% \text { (drop } \\
\text { out was similar in both } \\
\text { groups and respondents } \\
\text { and non-respondents did } \\
\text { not differ significantly). }\end{array}$ \\
\hline Colver $(1984)^{32}$ & $\begin{array}{l}\text { Asthmatic school } \\
\text { children in } \\
\text { disadvantaged } \\
\text { area of } \\
\text { Newcastle-upon- } \\
\text { Tyne. Before- } \\
\text { after study } 120 \\
\text { children (data on } \\
81 \text { ). }\end{array}$ & $\begin{array}{l}\text { Community based } \\
\text { asthma campaign, led by } \\
\text { school doctors. Children } \\
\text { identified are given } \\
\text { school doctor } \\
\text { consultation to explain } \\
\text { asthma and provide } \\
\text { information, letter sent } \\
\text { to family GP. }\end{array}$ & $\begin{array}{l}\text { Symptoms, } \\
\text { absence, attitudes } \\
\text { of school nurses } \\
\text { and doctors, } \\
\text { parents, teachers. } \\
\text { Home visit } 12 \\
\text { months after } \\
\text { school } \\
\text { consultation. }\end{array}$ & $\begin{array}{l}\text { Many children not identified during GP } \\
\text { consultations or routine medical checks. } \\
\text { At follow up, } 77 \% \text { of families thought } \\
\text { symptoms had improved, } 96 \% \text { found the } \\
\text { school doctor consultation helpful. } \\
\text { Teachers were more likely to let children } \\
\text { stay in school and keep their inhalers. }\end{array}$ & $\begin{array}{l}\text { Differences between follow } \\
\text { up and non-follow up not } \\
\text { reported. Descriptive } \\
\text { study, no statistical } \\
\text { analysis reported. }\end{array}$ \\
\hline Butz et al $(1994)^{33}$ & $\begin{array}{l}\text { Asthmatic } \\
\text { children from } 42 \\
\text { schools in } 2 \\
\text { Afro-American } \\
\text { inner city areas, } \\
\text { USA. Descriptive } \\
\text { study (part of } \\
\text { larger RCT). } 140 \\
\text { children. }\end{array}$ & $\begin{array}{l}\text { Use of CHW with low } \\
\text { income families. } \\
\text { Obtained information, } \\
\text { provided basic asthma } \\
\text { education, facilitated } \\
\text { access to medical care. } \\
\text { Children received } \\
\text { programme both with } \\
\text { and without school } \\
\text { based education } \\
\text { programme. }\end{array}$ & $\begin{array}{l}\text { Medication use, } \\
\text { emergency room } \\
\text { visits, housing } \\
\text { conditions. } 5 \\
\text { month } \\
\text { intervention } \\
\text { period (number } \\
\text { of CHW visits } \\
\text { not stated). }\end{array}$ & $\begin{array}{l}3 \text { CHWs dropped for inadequate } \\
\text { performance. All children who visited } \\
\text { emergency rooms were current } \\
\text { medication users. Most families had } \\
\text { carpeted floors, forced air heat, and } \geq 1 \\
\text { smoker. Use of plastic covers for bedding } \\
\text { was low. CHWs are effective in obtaining } \\
\text { information from families in inner city } \\
\text { communities. Limitations of their use } \\
\text { include lack of skills to assess medication } \\
\text { use and misuse, lack of familiarity with } \\
\text { abnormal physical findings. }\end{array}$ & $\begin{array}{l}\text { No comparison was made } \\
\text { of baseline severity of } \\
\text { asthma, nor was insurance } \\
\text { status of families reported. } \\
\text { Authors conclude that } \\
\text { CHW can provide valuable } \\
\text { service, but no conclusive } \\
\text { evidence to support this. }\end{array}$ \\
\hline Hughes et al (1991) & $\begin{array}{l}\text { Children } \\
\text { admitted to Izaak } \\
\text { Walton Killam } \\
\text { Children's } \\
\text { Hospital, Canada } \\
\text { with a diagnosis } \\
\text { of asthma. } \\
\text { Randomised } \\
\text { controlled trial. I: } \\
47 \text { patients ( } 44 \text { at } \\
\text { end) C: } 48 \\
\text { patients ( } 45 \text { at } \\
\text { end). }\end{array}$ & $\begin{array}{l}\text { Home and ambulatory } \\
\text { asthma management } \\
\text { programme. I: } \\
\text { Individual programme } \\
\text { by paediatric } \\
\text { respirologist. Inhaler } \\
\text { technique, in home } \\
\text { management of acute } \\
\text { exacerbations. } \\
\text { Education pamphlet, at } \\
\text { least two visits, } \\
\text { environmental checklist. } \\
\text { C: Treatment by } \\
\text { primary care physician, } \\
\text { attendance at clinic for } \\
\text { assessments at specified } \\
\text { intervals. }\end{array}$ & $\begin{array}{l}\text { Symptoms, } \\
\text { medication, } \\
\text { PEFR, physician } \\
\text { visits, school } \\
\text { absence, metered } \\
\text { aerosol } \\
\text { technique, } \\
\text { hospital } \\
\text { admissions, } \\
\text { asthma } \\
\text { knowledge. 1 year } \\
\text { intervention, 1 } \\
\text { year } \\
\text { postintervention. }\end{array}$ & $\begin{array}{l}\text { Significantly more primary care physician } \\
\text { visits by C during follow up. Flow rates } \\
\text { significantly lower in C, but differences } \\
\text { disappeared after } 1 \text { year. School } \\
\text { absenteeism fell for both groups. I } \\
\text { showed better inhaler technique. } \\
\text { Significantly fewer I families wanted } \\
\text { more asthma information at the end of } \\
\text { the study, more felt that their child took } \\
\text { responsibility for asthma management. } \\
\text { Programmes must be sustained to be } \\
\text { beneficial. Data suggest that costs to the } \\
\text { health insurance system of } C \text { patients } \\
\text { were more than I patients. }\end{array}$ & $\begin{array}{l}64 \% \text { response rate, } 6 \% \\
\text { drop out. The I group had } \\
\text { higher asthma knowledge } \\
\text { all the way through the } \\
\text { study, including prestudy. }\end{array}$ \\
\hline $\begin{array}{l}\text { Charlton et al } \\
(1994)^{35}\end{array}$ & $\begin{array}{l}\text { Admissions for } \\
\text { asthma or } \\
\text { attenders at a } \\
\text { paediatric } \\
\text { outpatient } \\
\text { department, } \\
\text { Winchester, } \\
\text { England. } \\
\text { Randomised } \\
\text { controlled trial } \\
\text { (by age, sex, } \\
\text { prophylaxis). I: } \\
48 \text { patients, C: } 43 \\
\text { patients. }\end{array}$ & $\begin{array}{l}\text { Nurse run asthma clinic. } \\
\text { I: Clinic in DGH } \\
\text { paediatric department. } \\
\text { Information on asthma } \\
\text { and self management } \\
\text { over and above standard } \\
\text { information. Reminders } \\
\text { for asthma review in } \\
\text { primary care. C: } \\
\text { Standard information, } \\
\text { no additional education } \\
\text { or reminders. }\end{array}$ & $\begin{array}{l}\text { Asthma } \\
\text { symptoms, peak } \\
\text { flow and } \\
\text { morbidity } \\
\text { questionnaire. } 12 \\
\text { month follow up. }\end{array}$ & $\begin{array}{l}\text { Significant differences between I and C } \\
\text { groups for days of activity restriction and } \\
\text { percentage of time spent with poor lung } \\
\text { function. Significantly more excellent and } \\
\text { less inappropriate patient/parent } \\
\text { responses to acute attack in I group. I } \\
\text { group patients more likely to make a } \\
\text { correct response than C. The nurse run } \\
\text { asthma clinic showed a tendency to } \\
\text { modify symptoms and peak flow. } \\
\text { Highlights the need for coordination } \\
\text { between hospital, patient, and primary } \\
\text { healthcare team. }\end{array}$ & $\begin{array}{l}\text { The number of inpatients } \\
\text { and outpatients is not } \\
\text { given, this could impact on } \\
\text { differences in severity. } \\
\text { Initial comparisons } \\
\text { between groups showed } \\
\text { differences, although no } \\
\text { tests were reported. }\end{array}$ \\
\hline Mayo et al $(1990)^{37}$ & $\begin{array}{l}\text { Adult asthmatic } \\
\text { patients admitted } \\
\text { to Bellevue } \\
\text { Hospital Center, } \\
\text { New York. } \\
\text { Randomised } \\
\text { controlled trial, } \\
\text { with non- } \\
\text { random } \\
\text { crossover. } \mathrm{I}=47 \\
\text { patients, } \mathrm{C}=57 \\
\text { patients, } \\
\text { crossover }=19 \\
\text { patients. }\end{array}$ & $\begin{array}{l}\text { Intensive outpatient } \\
\text { programme: I: } \\
\text { Education through } \\
\text { repeated contacts, no } \\
\text { written or audiovisual } \\
\text { materials. Patients } \\
\text { encouraged to } \\
\text { participate in decisions, } \\
\text { initiate self treatment, or } \\
\text { seek early emergency } \\
\text { room treatment. } \\
\text { Medical regimens } \\
\text { designed to encourage } \\
\text { compliance. C: Routine } \\
\text { clinic - details not given. }\end{array}$ & $\begin{array}{l}\text { Readmission, } \\
\text { hospital day rates, } \\
\text { treatment, patient } \\
\text { knowledge. } 8 \\
\text { month follow up. } \\
3 \text { years pre and } \\
\text { postenrolment. } 8 \\
\text { month } \\
\text { comparison two } \\
\text { years apart. }\end{array}$ & $\begin{array}{l}\text { No patient showed satisfactory MDI } \\
\text { technique, asthma knowledge and } \\
\text { treatment options were vague. Hospital } \\
\text { use less in I, and readmission and } \\
\text { hospital day rate fell. Reductions were } \\
\text { found for patients in the crossover group. } \\
\text { Readmission rate constant, suggesting } \\
\text { sustained benefit of clinic. Costs } \\
\text { estimated at } \$ 1500 \text { per patient for } 8 \\
\text { months, compared with } \$ 4000 \text { for } \\
\text { routine care. Physician } \\
\text { accessibility/accountability was } \\
\text { important. Nurse practitioners may be as } \\
\text { effective as physicians in reducing } \\
\text { readmission rates among difficult adult } \\
\text { asthmatics. }\end{array}$ & $\begin{array}{l}\text { Exclusion of potentially } \\
\text { non-compliant patients } \\
\text { may lead to overestimation } \\
\text { of the impact of the } \\
\text { intervention. Inclusion } \\
\text { criteria are not consistently } \\
\text { reported and it is unclear } \\
\text { why randomisation was } \\
\text { unequal. Useful discussion } \\
\text { about the need for an } \\
\text { individualised approach, } \\
\text { and to combine the role of } \\
\text { educator and medical } \\
\text { provider. }\end{array}$ \\
\hline
\end{tabular}




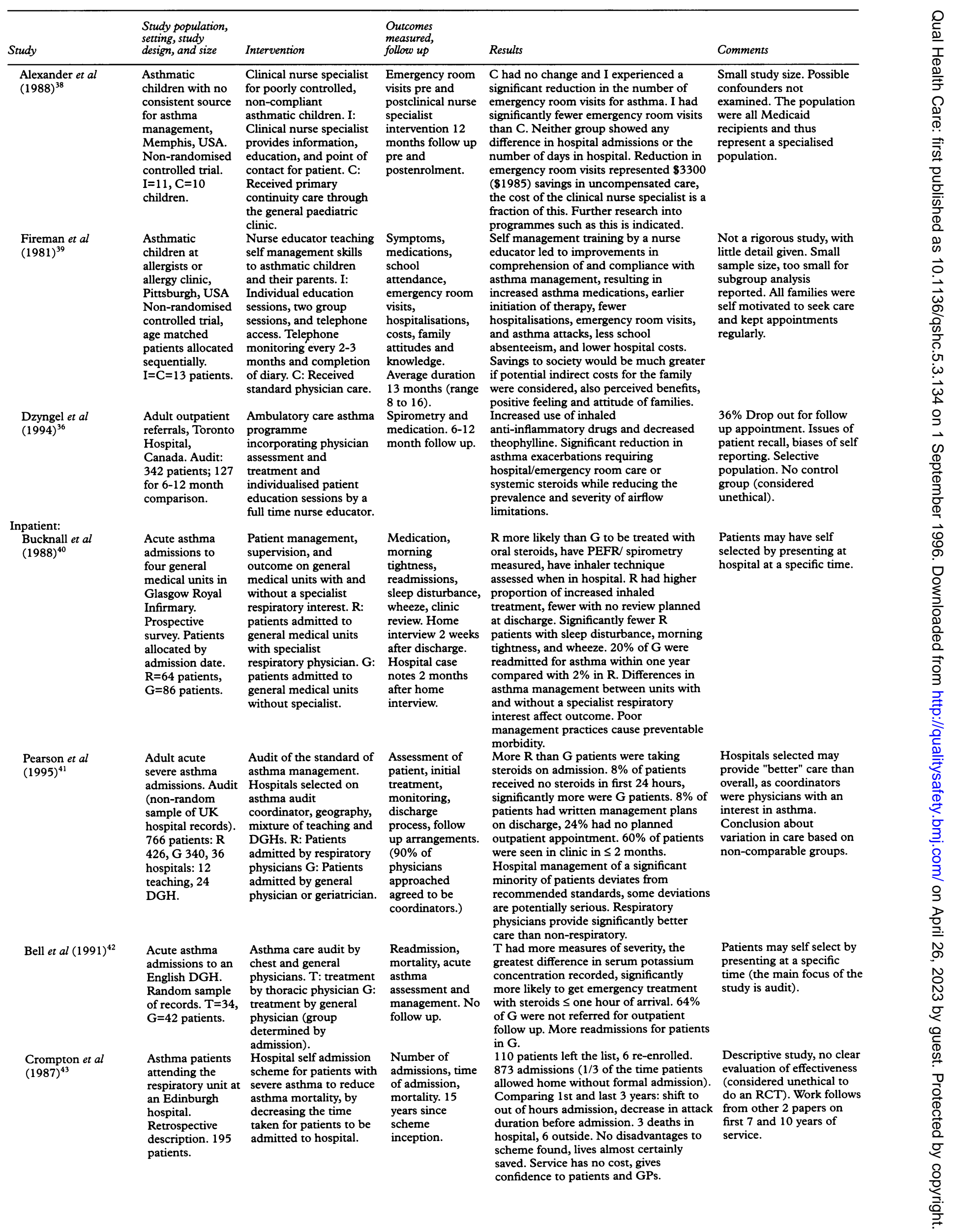




\begin{tabular}{|c|c|c|c|c|c|}
\hline Study & $\begin{array}{l}\text { Study population, } \\
\text { setting, study } \\
\text { design, and size }\end{array}$ & Intervention & $\begin{array}{l}\text { Outcomes } \\
\text { measured, } \\
\text { follow up }\end{array}$ & Results & Comments \\
\hline \multicolumn{6}{|l|}{ Emergency: } \\
\hline $\begin{array}{l}\text { Maiman et al } \\
(1979)^{44}\end{array}$ & $\begin{array}{l}\text { Adult asthmatic } \\
\text { patients admitted } \\
\text { to emergency } \\
\text { department, } \\
\text { Baltimore, USA. } \\
\text { RCT }(3 \times 2) \times 2 \times 2 \\
\text { sequential } \\
\text { intervention } \\
\text { introduction. } 245 \\
\text { patients. }\end{array}$ & $\begin{array}{l}\text { Interventions: } \\
\text { Interpersonal similarity } \\
\text { (nurse intervention by } \\
\text { identified; unidentified } \\
\text { asthmatic; } \\
\text { non-asthmatic); positive } \\
\text { written appeal (booklet; } \\
\text { no booklet). Stage } 1 \\
\text { intervention, stage } 2 \\
\text { interview, stage } 3 \text { follow } \\
\text { up nurse reinforcement } \\
\text { by telephone. }\end{array}$ & $\begin{array}{l}\text { Visits to } \\
\text { emergency } \\
\text { department. } 2 \\
\text { weeks in each } \\
\text { intervention arm } \\
\text { before the next } \\
\text { treatment. Only } \\
\text { short term results } \\
\text { reported in this } \\
\text { paper. }\end{array}$ & $\begin{array}{l}\text { Significant asthmatic nurse effect } \\
\text { (identified or unidentified). No effect } \\
\text { found for the book, nurse-book } \\
\text { interaction, or interview. From initial } \\
\text { interview to telephone follow up, there } \\
\text { was a significant nurse effect for the } \\
\text { asthmatic nurse intervention compared } \\
\text { with the non-asthmatic. Interpersonal } \\
\text { similarity should be taken into account, } \\
\text { role of information seems to be modified } \\
\text { by its source. }\end{array}$ & $\begin{array}{l}\text { The study methodology is } \\
\text { not very clearly explained, } \\
\text { and intervention group } \\
\text { numbers are not reported. } \\
\text { Follow up is very short } \\
\text { term ( } 2 \text { weeks) for each } \\
\text { intervention, this would } \\
\text { not necessarily be long } \\
\text { enough to determine } \\
\text { behaviour. }\end{array}$ \\
\hline Joe et al $(1992)^{45}$ & $\begin{array}{l}\text { Emergency } \\
\text { department } \\
\text { residents and } \\
\text { adult asthmatic } \\
\text { patients, } \\
\text { Tennessee USA. } \\
\text { Non-randomised, } \\
\text { single blind } \\
\text { observational } \\
\text { study A: } 8 \\
\text { residents, } 82 \\
\text { patients B: } 8 \\
\text { residents, } 139 \\
\text { patients C: } 8 \\
\text { residents, } 129 \\
\text { patients. }\end{array}$ & $\begin{array}{l}\text { A: Short verbal } \\
\text { presentation to residents } \\
\text { on emergency } \\
\text { department rotation, } \\
\text { literature summary and } \\
\text { protocols. B: A, plus } \\
\text { long term } \\
\text { anti-inflammatory } \\
\text { treatment at discharge. } \\
\text { C: control group, no } \\
\text { intervention. (Residents } \\
\text { prescribing patterns } \\
\text { were covertly collected.) }\end{array}$ & $\begin{array}{l}\text { Acute and } \\
\text { discharge } \\
\text { treatment, length } \\
\text { of stay. From } \\
\text { entry into } \\
\text { emergency } \\
\text { department until } \\
\text { discharge. }\end{array}$ & $\begin{array}{l}\text { Emergency department } \beta \text { agonist } \\
\text { treatment similar for all } 3 \text { groups, low } \\
\text { theophylline use more pronounced in A } \\
\text { and B. Nebulisation, steroids greater in A } \\
\text { and B than C. At discharge, A had more } \\
\text { tapering prednisone than C and B, more } \\
\text { use of } \beta \text { agonists then B. Inhaled steroids } \\
\text { had more use in B than C. Theophylline } \\
\text { lower in A and B compared with C. No } \\
\text { difference in length of stay between } \\
\text { groups. Intervention is effective in } \\
\text { improving acute management prescribing } \\
\text { patterns, but partially effective in } \\
\text { optimising discharge treatment. }\end{array}$ & $\begin{array}{l}\text { Severity of asthma on } \\
\text { presentation and physician } \\
\text { characteristics are not } \\
\text { reported, and could differ } \\
\text { between groups. The text } \\
\text { of the results does not } \\
\text { concur with the tables for } \\
\text { the prescribing patterns } \\
\text { (both acute and } \\
\text { discharge). Some } \\
\text { conclusions do not follow } \\
\text { from the results. }\end{array}$ \\
\hline $\begin{array}{l}\text { Connett et al } \\
(1993)^{46}\end{array}$ & $\begin{array}{l}\text { Acute asthmatic } \\
\text { children } \\
\text { presenting at } \\
\text { hospital in } \\
\text { Brighton. } \\
\text { Before-after } \\
\text { study. I. } 197 \\
\text { children, } 158 \\
\text { seen by registrar, } \\
39 \text { seen by SHO } \\
\text { II. } 687 \text { children. }\end{array}$ & $\begin{array}{l}\text { I. Replacement of SHOs } \\
\text { with registrar for } \\
\text { admission decisions. II. } \\
\text { SHO training with home } \\
\text { treatment package for } \\
\text { acute asthmatic children. } \\
\text { I. Assessment by } \\
\text { registrar/SHO } \\
(80 \% / 20 \%) v \text { SHO } \\
\text { preintervention. II. } \\
\text { Assessment by SHO } \\
\text { with education } v \text { SHO } \\
\text { before education. }\end{array}$ & $\begin{array}{l}\text { Admissions and } \\
\text { readmissions (I } \\
\text { and II), } \\
\text { symptom, } \\
\text { daytime cough } \\
\text { and wheeze, } \\
\text { activity, } \\
\text { medications (II). } \\
\text { I. 1 week; II. 2 } \\
\text { week follow up. } \\
\text { Some patients } \\
\text { sent diary cards. }\end{array}$ & $\begin{array}{l}\text { I. } 34(15) \% \text { of children seen by registrar } \\
\text { SHO were sent home, } 9(3) \% \text { of whom } \\
\text { reattended in } \leq 1 \text { week, } 2(3) \% \text { were } \\
\text { admitted. More children sent home } \\
\text { compared with previously. II. } 44 \% \text { of } \\
\text { children seen by "educated" SHOs were } \\
\text { sent home, } 5 \% \text { of whom reattended in } \leq \\
1 \text { week, } 2 \% \text { subsequently admitted. } \\
\text { Referrals were similar to previous years, } \\
\text { but fewer admissions. More children sent } \\
\text { home in study compared with previously. }\end{array}$ & $\begin{array}{l}\text { Not a rigorous study, no } \\
\text { comparison of groups, or } \\
\text { measure of asthma } \\
\text { severity. Not randomised. } \\
\text { Impact of previous } \\
\text { admissions may reflect on } \\
\text { current admissions (only } \\
45 \% \text { of those admitted and } \\
61 \% \text { of those not admitted } \\
\text { returned the diary cards). }\end{array}$ \\
\hline
\end{tabular}

$\mathrm{I}=$ intervention group $\mathrm{C}=$ control group $\mathrm{RCT}=$ randomised controlled trial; $\mathrm{CHW}=$ community health worker; $\mathrm{DGH}=$ district general hospital; $\mathrm{SHO}=$ senior house officer; $\mathrm{HMO}=$ health maintenance organisation; $\mathrm{MDI}=$ metered dose inhaler; PEFR = peak expiratory flow rate.

\section{Conclusions}

There is a lack of good quality research evaluating organisational aspects of the delivery of asthma care. No conclusive evidence has been identified to favour any particular organisational form, although limited evidence would suggest that specialist care is associated with better outcomes than care provided by non-specialists. Also, shared care under certain circumstances can be as effective as hospital led care in the treatment of adults with asthma. Further research, with long term follow up, is required to provide reliable evidence to inform policy. Of particular interest is the question of who delivers asthma care, to find whether patients treated by healthcare professionals with expertise and interest in asthma, independent of setting, will experience better outcomes.

Attention should move away from looking solely at individual treatments to looking at complete packages of treatment and their component parts. Carefully designed and well thought out randomised controlled trials are needed to identify the specific aspects of organisation to inform policy makers. As noted in the case of shared care for diabetes, changes in the delivery of care are being implemented before they have been fully evaluated. ${ }^{56}$ There is a need for thorough evaluation of such programmes (with long term follow up) before widespread implementation.

We are grateful to Julie Glanville and Maureen Quinn for carrying out database searches, and the useful comments of the editor and three anonymous referees. AJE and TAS are both supported by the Department of Health. This work was carried out as part of the ongoing project developing health outcome indicators, led by Dr Azim Lakhani, Director of the Central Health Outcome Unit at the Department of Health.

\section{Appendix \\ SEARCH STRATEGY \\ Strategy 1:}

1 exp delivery of health care/

2 asthma/cl,co,di,dh,dt,ec,ep,eh,et,ge,mo, nu,ph,pp,pc,px,th

3 limit 2 to english language

4 limit 3 to human

\section{1 and 4}

\section{Strategy 2:}

1 asthma.tw

2 exp delivery of health care/

3 exp ambulatory care/

4 exp ambulatory care facilities/

5 outpatients

6 (nursing adj clinic\$).tw.

7 exp specialties, nursing/

8 (asthma adj clinic\$).tw.

9 (centre or center).tw.

101 and 9

11 (general adj practice).tw. 
12 (family adj practice \$).tw.

13 primary health care/

14 continuity of patient care/

15 exp home care services/

16 or/2-7,11-15

171 and 16

188 or 10

1918 not 17

20 (asthma adj clinic).tw.

21 (asthma and setting).tw.

2210 or 20

2321 or 22

2417 or 23

1 Bucknall C. Management of asthma and the audit spiral. Ouality in Health Care 1992;1:224.

2 Usherwood T, Barber J. General practice audit of the care of children with asthma. $B M F$ 1985;291:254.

3 Ebden P, Carey O, Quinton D, Cookson J. A study of acute asthma in the accident and emergency department. $B r \mathcal{F}$ Dis Chest 1988;82:162-7.

4 Henry R, Fitzclarence C, Henry D, Cruickshank D. What do health care professionals know about childhood asthma? $\mathcal{F}$ Paediatr Child Health 1993;29:32-5.

5 Barnes G, Partridge M. Community asthma clinics: 1993 survey of primary care by the National Asthma Task Force. Quality in Health Care 1994;3:133-6.

6 Interiano B, Guntupalli K. Metered-dose inhalers. Do health care providers know what to teach? Arch Intern Med 1993;153:81-5.

7 British Thoracic Society, Research Unit of the Royal College of Physicians of London, Kings Fund, and National Asthma Campaion. Guidelines for management of asthma in adults: I - chronic persistent asthma. BMf of asthma in adust

8 British Thoracic Society, Research Unit of the Royal College of Physicians of London, Kings Fund, and National Asthma Campaign. Guidelines for management of asthma in adults: II - acute severe asthma. $B M \mathcal{F}$ 1990;301:797-800.

9 British Thoracic Society, British Paediatric Association, Research Unit of the Royal College of Physicians of London, King's Fund Centre, National Asthma Campaign, Royal College of General Practitioners, et al. Guidelines on the management of asthma. Thorax 1993;48:S1-24.

10 Neville $R$, Clark R, Hoskins G, Smith B. National asthma attack audit. $B M \Im$ 1993;306:1991-2.

$11 \mathrm{Phin}$ S, Oates R. Variations in the treatment of childhood asthma. Med $₹$ Aust 1993;159:662-6.

12 Lipworth B, Jackson C, Ziyaie D, Winter J, Dhillon P, Clark $\mathrm{R}$, et al. An audit of acute asthma admissions to a respiratory unit. Health Bull 1992;50:389-98.

13 Keeley D. How to achieve better outcome in treatment of asthma in general practice. $B M F$ 1993;307:1261-3.

14 NHS Management Executive. GP contract health promotion package: guidance on implementation. Department of Health. FHSL, 1993;3.

15 Hickman M, Drummond N, Grimshaw J. A taxonomy of shared care for chronic disease. $\mathcal{F}$ Public Health Med 1994; 16:447-54.

16 Orton P. Shared care. Lancet 1994;344:1413-5.

17 NHS centre for reviews and dissemination. Guidelines for undertaking systematic reviews of effectiveness. York: Univerundertaking systematic reviews of effectiveness

18 Drummond $\mathrm{N}$, Abdalla $\mathrm{M}$, Buckingham J, Beattie J, Lindsay T, Osman L, et al. Integrated care for asthma: a clinical, social, and economic evaluation. Grampian clinical, social, and economic evaluation. Grampian 1994;308:559-64.

19 Buckingham K, Drummond N, Cameron I, Meldrum P, Douglas G. Costing shared care. Health Services Management 1994;February:22-5.

20 van Damme $R$, Drummond N, Beattie J, Douglas G. Integrated care for patients with asthma: views of general practitioners. Br f Gen Pract 1994;44:9-13.

21 Usherwood T, Barber J. Audit of process and outcome in a mini-clinic for children with asthma. Fam Pract 1988; 5:289-93.

22 Martys C. Asthma care in Darley Dale: general practitioner audit. $B M \mp$ 1992;304:758-60.

23 Charlton I, Charlton G. Broomfield J, Campbell M. An evaluation of a nurse-run asthma clinic in general practice evaluation of a nurse-run asthma clinic in general practice using an attitudes

24 Charlton I, Charlton G, Broomfield J, Mullee M. Audit of the effect of a nurse run asthma clinic on workload and patient morbidity in a general practice. $\mathrm{Br} \mathcal{F}$ Gen Pract 1991;41:227-31.

25 Bryce F, Neville R, Crombie I, Clark R, McKenzie P. Controlled trial of an audit facilitator in diagnosis and treatment of childhood asthma in general practice. $B M \mathcal{J}$ 1995;310:838-42.
26 Barritt $P$, Staples E. Measuring success in asthma care: a repeat audit. Br $\mathcal{F}$ Gen Pract 1991;41:232-6.

27 Modell M, Harding J, Horder E, Williams P. Improving the care of asthmatic patients in general practice. $B M \mathcal{F}$ 1983;286:2027-30.

28 Carswell F, Robinson E, Hek G, Shenton T. A Bristol experience: benefits and cost of an 'asthma nurse' visiting experience: benefits and cost of an 'asthma nurse' visiting
the homes of asthmatic children. Bristol Medico-Chirurgical fournal 1989;104:11-2.

29 Mitchell E, Ferguson V, Norwood M. Asthma education by community child health nurses. Arch Dis Child 1986; 61:1184-9.

30 Greineder D, Loane K, Parks P. Reduction in resource utilization by an asthma outreach program. Arch Pediatr Adolesc Med 1995;149:415-20.

31 Hill R, Williams J, Britton J, Tattersfield A. Can morbidity associated with untreated asthma in primary school children be reduced? A controlled intervention study. $B M F$ 1991;303:1169-74.

32 Colver A. Community campaign against asthma. Arch Dis Child 1984;59:449-52.

33 Butz A, Malveaux F, Eggleston P, Thompson L, Schneider $\mathrm{S}$, Weeks $\mathrm{K}$, et al. Use of community health workers with inner-city children who have asthma. Clin Pediatr (Phila) 1994;33:135-41.

34 Hughes D, McLeod M, Garner B, Goldbllom R. Controlled trial of a home and ambulatory program for asthmatic children. Pediatrics 1991;87:54-61.

35 Charlton I, Antoniou A, Atkinson J, Campbell M, Chapman $\mathrm{E}$, Mackintosh $\mathrm{T}$, et al. Asthma at the interface: bridging the gap between general practice and a district general the gap between general practice and
hospital. Arch Dis Child 1994;70:313-8.

36 Dzyngel B, Kesten S, Chapman K. Assessment of an ambulatory care asthma program. F Asthma 1994;31:291-300.

37 Mayo P, Richman J, Harris H. Results of a program to reduce admissions for adult asthma. Ann Intern Med 1990; 112:864-71.

38 Alexander J, Younger R, Cohen R, Crawford L. Effectiveness of a nurse-managed program for children with chronic asthma. $\mathcal{F}$ Pediatr Nurs 1988;3:312-7.

39 Fireman P, Friday G, Gira C, Vierthaler W, Michaels L. Teaching self-management skills to asthmatic children and their parents in an ambulatory care setting. Pediatrics 1981;68:341-8.

40 Bucknall C, Robertson C, Moran F, Stevenson R. Differences in hospital asthma management. Lancet 1988; i:748-50.

41 Pearson M, Ryland I, Harrison B. National audit of acute severe asthma in adults admitted to hospital. Quality in Health Care 1995;4:24-30.

42 Bell D, Layton A, Gabbay J. Use of a guideline based questionnaire to audit

43 Crompton G, Grant I, Chapman B, Thomson A, McDonald $C$. Edinburgh emergency asthma admission service: report on 15 years' experience. European fournal of Respiratory Disease 1987;70:266-71.

44 Maiman L, Green L, Gibson G, MacKenzie E. Education for self treatment by adult asthmatics. $\mathcal{f} A M A$ 1979; 241:1919-22.

45 Joe R, Kellerman A, Arheart K, Ellis R, Self T. Emergency department asthma treatment protocol. Ann Pharmacother 1992;26:472-6.

46 Connett G, Warde C, Wooler E, Lenney W. Audit strategies to reduce hospital admild $1993 ; 69: 202-5$.

47 Lambert M, Arblaster L, Entwistle V, Foster M, Sheldon T, Watt I. Review of the research on the effectiveness of health service interventions to reduce variations in health. York: Uniservice interventions to reduce variations in health

48 Clark N. Asthma self-management education: research and implications for clinical practice. Chest 1989;95:1110-3.

49 Lipworth B, Allan J, Jackson C, Dhillon P, Winter J, Clark $\mathrm{R}$, et al. An audit of hospital discharge letters in patients admitted with acute asthma. Scott Med $₹$ 1993;38:1 16-9.

50 Partridge $M$. Delivering optimal care to the person with asthma: what are the key components and what do we mean by patient education? Eur Respir f 1995;8:298-305.

51 Weiss K, Budetti P. Examining issues in health care delivery for asthma. Background and workshop overview. Med Care 1993;31:MS9-19.

52 Greenhalgh P. Shared care for diabetes: a systematic review. London: R Coll Gen Pract 1994.(Occasional Paper 67.)

53 Henry R, Milner A. Specialist approach to childhood asthma: does it exist? $B M \mathcal{F}$ 1983;287:260-1.

54 Fitzgerald J, Freund D, Hughett B, McHugh G. Influence of organizational components on the delivery of asthma care. Med Care 1993;31:MS61-73.

55 Central Research and Development Committee Advisory Group. Identifying $R$ and $D$ priorities for the NHS on asthma management. Leeds: Department of Health, 1995.

56 Sowden A, Sheldon T, Alberti G. Shared care in diabetes: better evaluation is needed. $B M F$ 1995;310:142-3. 